\title{
Biojet from Hydroconversion of Camelina Oil Mixed with Straight Run Gas Oil
}

\begin{abstract}
ALEXANDRU TEPELUS, PAUL ROSCA*, RALUCA DRAGOMIR
Petroleum - Gas University of Ploiesti, 39 Calea Bucuresti,100520, Ploiesti, Romania

In the current research study camelina non edible oil (CO) was used as renewable feedstock for production of jet fuel by hydroconversion processes. The vegetable oil was mixed with straight run gas oil (SRGO) at 10, 15 and $20 \%$ ratio. The hydrotreating experiments were carried out in micropilot plant flow reactor over $\mathrm{NiMo} / \mathrm{Al}_{2} \mathrm{O}_{3}$ catalyst at $350^{\circ} \mathrm{C}$ and $380^{\circ} \mathrm{C}, 80$ bar pressure $1 \mathrm{~h}^{-1}$ and $1.5 \mathrm{~h}^{-1}$ liquid hourlyspace velocity (LHSV). The research focuses on the influence of the SRGO-CO ratio, temperature and LHSV on the yields and the physiochemical properties of the biojet $\left(160-300^{\circ} \mathrm{C}\right)$ obtained. The hydrotreating reactions which occur during the process, produce $36-45 \%$ wt jet yields but bad flow properties due to the n-paraffins with 13-20 carbon atoms in molecules obtained from hydrogenation of vegetable oil. These characteristics can be corrected by hydroisomerisation. The results show that the hydrotreatment of CO and SRGO-CO mixtures are an alternative for biofuel production with characteristics similar to jet fuel.
\end{abstract}

Keywords: Camelina oil; Biojet fuel; Hydroprocessing; Hydroteating; Straight run gas oil; Freezing point

Economic and social development has increased demand of energy, especially fossil fuels based energy which is mainly used by the transportation industry. The transportation industry currently requires between 20 to $25 \%$ of the total share of energy butt its energy demand is increasing year by year. Based on current data, it estimates a growing demand for energy of $2 \%$ a year for the 20162040 time frame, while the peak for production of oil will be between 2020-2030 [1-3]. Usage of fossil fuels generates $\mathrm{CO}_{2}$, the main green house gas (GHG) responsible for global warming.

Out of the transportation industry, the aviation sector is the highest speed network of transportation, which has an important and vital role in global commerce, tourism and the military. According to statistical data regarding air transportation presented by International Civil Aviation Organization (ICAO) in 2017, the total number of passengers transported by airplanes has increased to 4.1 billion, the number of departures has reached 36.7 million and over 56 million tons were transported by air [ 4,5$]$. This is why, following the trend for increasing demand of energy, the air traffic is expected to increase in the next 20 years with an average annual rate of $4.5 \%$. The air transportation sector provides almost 65 million jobs and indirectly employs another several million workers [6].

Global aviation industry energy consumption in 2017 was estimated at 90 billion gallons of jet fuel while the estimate for 2018 is around 94 billion gallons of jet fuel. The quantity of fuel used for air transportation represents $2 \%$ of the global $\mathrm{CO}_{2}$ emissions $[7,8]$.

J et fuel's content is made out of paraffins, olefins and aromatics with 8 to 16 carbons, distributed in the fuel in such a way it fulfills the requirements of the ASTM D1655 standard: high energy per unit of mass (heat of combustion), high flash point, low freezing point, a good thermal stability and good lubricity $[9,10]$. Paraffins have the highesthydrogen/carbon ratio, offer the highest quantity of energy per unit of mass and have a clean burn without smoke emissions or any other solid particles. Out of the paraffins, it's preferred to have isoparaffins since they have a lower freezing point than the n-paraffins. Naphthenes have a lower hydrogen/carbon ratio but their density is higher than the paraffins and the heat of combustion is comparable with the one of paraffins. Also, the naphthenes have a lower freezing point. Aromatics have the lowest hydrogen/carbon ratio out of all the hydrocarbons that make up the jet fuel. They have the lowest energetic content per unit of volume [11,12].

Because of the high density, they have a specific energy content close to the one of paraffins and naphthenes, but the aromatic contentin jet fuel is limited to $20-25 \%$ volume because by burning aromatics, it results in smoke and particulate matter (soot) which affects the mechanical components of the engine. A small content of aromatic hydrocarbons is needed as their effect is to protect the gaskets and seals from losing their elasticity which would lead to fuel leakage [13,14].

The total dependency of fossil fuel is forcing the aviation sector to find solutions for decreasing the polluting emissions and help with fossil fuel preservation. The last two decades, the concern for the negative impact of fossil fuels on the environment and the increase of fossil fuel energy has increased which has led governments to develop projects and technologies for sustainable alternative sources of energy [12,14-17].

Obtaining an alternative and sustainable biojet is difficult since these biojet fuels have to respect strict criteria that are imposed by flight safety. Several technologies have been developed with the purpose of producing biojet from renewable sources, and the most important are:

The AT] (Alcohol-to-jet) $[12,14,18,19]$ process converts alcohols into jet fuel through a number of processes: dehydration, oligomerization, distillation and hydration of the product in order to obtain the final fuel. The main alcohols used are methanol, ethanol, isobutanol, nbutanol and some branched fatty alcohols. In order to have a sustainable process, the alcohols are obtained from the biomass and come from sugar cane and sugar bead cultures but other sources are used like the hydrolysis of starch, hydrolysis of Polysaccharides from lignocellulose biomass etc.

\footnotetext{
*email: prosca@upg-ploiesti.ro
} 
The GT] (Gas-to-J et) [12,20,21] process is based on the Fischer-Tropsch process and has the potential to produce liquid hydrocarbons from syngas. Syngas can be obtained through gasification of the biomass which is not used by the food industry or of the waste derived from biomass. The production of renewable fuels through the FischerTropsch via biosyngas (FT-BTL) is encouraging because fuels produced though this method are carbon neutral.

The STJ (Sugar-to-J et) $[12,14,22,23]$ is a promising technology for producing biojet which involves the biological conversion in an aerobic environment of different types of sugars like sucrose (from sugar cane and sugar bead), lignocellulosic sugar from the hydrolysis of hemicelluloses or celluloses into products like farnesene, fatty esters, fatty alcohols [12].

The company Amyris is the one that has developed this technology, by using special yeasts in order to ferment sugars in an aerobic environment and obtaining an intermediate product called farnesene. Farnesenes are recovered and separate, having a purity between $96-97 \%$, after which they're hydrogenate to farnesane. Starting with 2014, blending of jet fuel A/A1 of the farnesane has been admitted by the ASTM with a maximum limit of $10 \%$. In order to have a $100 \%$ biojet, the farnesane has to be hydrocracked and hydroisomerized [12,14,24,25].

Vegetable oils are a good alternative for producing biojet. The main oils used for this are canola, soybean, rapeseed, corn, palm tree and camelina. Other sources with a high yield for producing oils are cultures of algae. The main technology approved by the ASTM standard for a blending with jet fuel is called HRJ (Hydroprocessed Renewable Jet) or HEFA (Hydroprocessed Esters and Fatty Acids) $[12,14,15,24,26]$. The main advantages of the HRJ are: the technology is already mature and available on an industrial scale, the biojet resulted from the HRJ is a good equivalent of the classic jet fuel with the advantage of having a lower aromatic content, a lower sulfur content and the emissions of GHG are lower. Also, the hydrotreating process can use vegetable oils in a mixture with fossil jet, in order to better control the aromatic and sulfur content in jet fuel [17].

The biojet has a different composition from the conventional jet fuel, because it's main content is made out of $n$-paraffins and isoparaffins with a low content of aromatics and cycloalkenes. Because of this, the blending of biojet and conventional jet is limited to a maximum $50 \%-50 \%$, but even at this ratio of blending the impact on the environment and the quality of air is greatly improved. The different types of biojet have low quantities of sulfur, so a blending with conventional jet fuel would reduce considerably the sulfur content.

Using biofuels in order to reduce the impact over the environment and the energetic dependency on fossil fuels has to be correlated with the technical feasibility and economic viability of technologies, with the sustainability of raw materials on the long run and with allocating biomass resources for food production.

An attractive raw material for obtaining biojet is Camelina, which is a plant from Northern Europe that does not compete with the plants used for food by the population. It grows fast and is resilient to severe climate conditions. The camelina cultures can be grown in the same areas the wheatcultures grow once every three years for a crop rotation. The camelina cultures offer several advantages: it maintains the nutrients in the soil, it retains humidity in the soil and ithelps increase the yield production for the next crops that are being grown on that plot of land. $[12,14,15,26-32]$

The estimated cost for sustainable jet fuel varies according to the feedstock used and desired path of production, butit's generally ranged between $0.8-2.2$ Euro/ liter, which is much higher than the price of conventional J et A-1 which is priced at around 0.25 Euro/L. [33]

The objective of this paper is to obtain biojet through the process of hydroconversion of different mixtures of camelina oil with SRGO. We analyze the influence of the reaction conditions over the yields and the main characteristics of the biojet we obtained.

\section{Experimental part}

\section{Feedstocks and catalysts}

For the experimental study, it has been used a mixture of Straight Gas Run Oil (SRGO)- Camelina Oil (CO) with 10,15 and $20 \%$ volume of $\mathrm{CO}$.

\section{Micropilotplant}

The hydroconversion experiments were carried out in a micropilot plant (fig. 1) by using a fix bed reactor with a volume of $60 \mathrm{~cm}^{3}$ of catalyst.

The experimental conditions are: temperature: $350{ }^{\circ} \mathrm{C}$ and $380{ }^{\circ} \mathrm{C}$; pressure: 80 bar; LHSV: 1 and $1.5 \mathrm{~h}^{-1}$ and 600 $\mathrm{cm}^{3} / \mathrm{cm}^{3} \cdot \mathrm{H}_{2}$ /feedstock ratio.

The liquid phase is dried with $\mathrm{CaCl}_{2}$, in order to eliminate the traces of water resulted in the deoxygenation reactions of the fatty acids from the composition of the vegetable oil, afterwards the liquid phase is weighted for establishing the yield in a hydrotreated product.

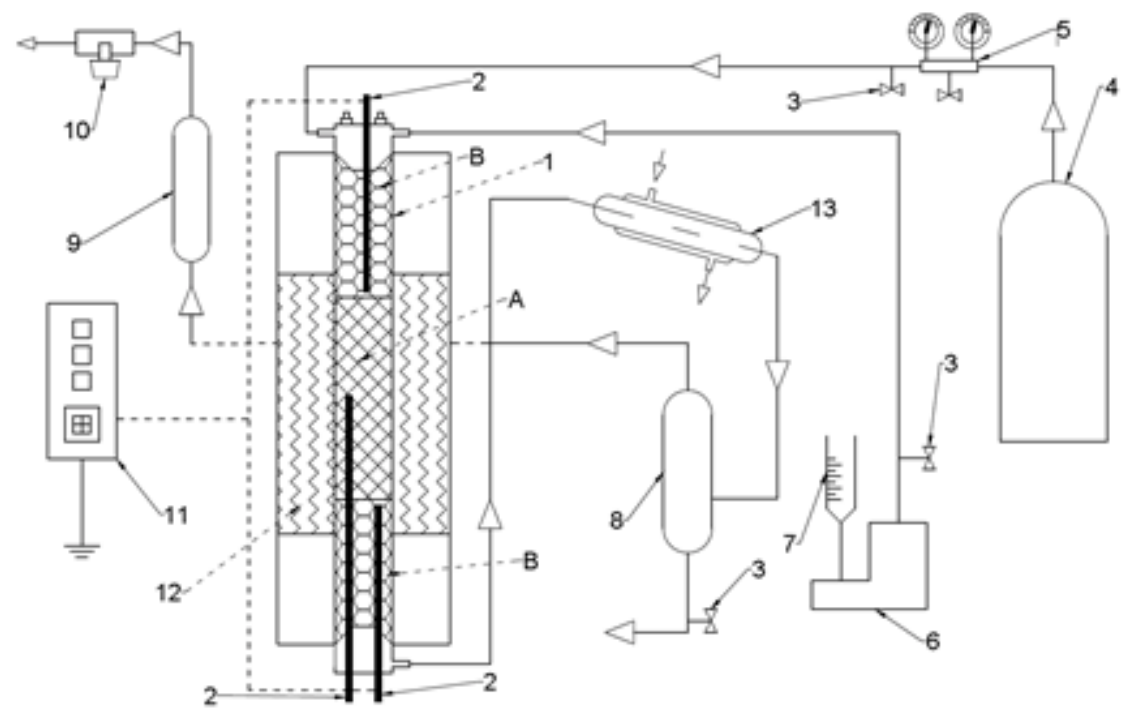

Fig. 1. The hydroconversion micropilot plant A- Catalyst; B-filling layer;1-reactor;

2-thermocuple, 3-safety valve, 4- hydrogen tank, 5- pressure regulator, 6-metering pump,

7- feedstock burette, 8-high pressure separator, 9-buffer tank for gases,

10- flowmeter,11-temperature register and control panel, 12- electrical heater, 13- water cooler 
The dried hydrotreated liquid product is separated through PRF distillation in three fractions: gasoline (IBP$\left.160^{\circ} \mathrm{C}\right)$; jet fuel $\left(180-300^{\circ} \mathrm{C}\right)$ and a heavier phase $(300+$ $\left.{ }^{\circ} \mathrm{C}\right)$.

The resulted biojet from hydrotreatment has been characterized for determining the density (EN ISO 12185); the freezing point (SR 13552); flash point (SR 5489). The chemical composition of the liquid product obtained through hydroconversion of $\mathrm{CO}$ has been determined by chromatography/mass spectrometry analysis on a GC-MS CP-3800 Triple Quad Agilent Technologies machine.

For identification and analysis of the reaction mixtures, a NIST library has been used and it was determined with the parameters presented in the table 1.

\section{Results and discussions}

The main characteristics of the CO and SRGO are presented in table 2, the True Boiling Point (TBP) Distillation Curve of SRGO in table 3, while the composition in fatty acids of the $\mathrm{CO}$ in table 4.

The data from table 4 shows that the $\mathrm{CO}$ is made out of unsaturated fatty acids in a proportion of $90.62 \%$ and the rest of $9.38 \%$ represents saturated fatty acids. The unsaturated fatty acids mostly contain carbons chains with 18 atoms in the molecule and are linolenic (48.23\%), linoleic (20.99\%) and oleic (16.27 \%), and the saturated fatty acids contain 16 atoms in the molecule like the palmitic acid (6.51\%).

The hydroconversion reactions were carried out on an industrial catalyst, $\mathrm{NiMo} / \mathrm{Al}_{2} \mathrm{O}_{3}$, with a specific surface of $219.3 \mathrm{~m}^{2} / \mathrm{g}$, the pore volume of $1.323 \mathrm{~cm}^{3} / \mathrm{g}$ and the average pore dimension of $3.52 \mathrm{~mm}$. The textural characteristics of the catalyst have been determined on an Autosorb 1 Quantacrome machine by recording and automatic processing of the linear adsorption isotherms of nitrogen. The specific surface has been calculated by using the BET equation in the linear part of the adsorption isotherm. For the evaluation of distribution of pores and pore dimensions, it has been used the desorption branch of the isotherm with hysteresis applying the $\mathrm{BJ} \mathrm{H}$ method. The strength and distribution of acidity in the catalyst have been determined through thermodesorption with diethylamine and are presented in figure 2 and table 5.

\begin{tabular}{|c|c|}
\hline GC Method & MS Method \\
\hline $\begin{array}{c}\text { HP-5 } 5 \% \text { Phenyl Methyl Siloxan } \\
(\mathrm{L}=30 \mathrm{~m}, \mathrm{D}=320 \mu \mathrm{m}, \mathrm{d}=0,25 \mu \mathrm{m})\end{array}$ & $\begin{array}{c}\text { QQQ Collision Cell EPC: } \\
\text { Flow Quench } \mathrm{Gas}(\mathrm{He})=2,2 \mathrm{ml} / \mathrm{min} ; \mathrm{N} 2 \\
\text { Flow Collision Gas }(\mathrm{N} 2)=1,5 \mathrm{ml} / \mathrm{min} ;\end{array}$ \\
\hline $\begin{array}{c}\text { Heater progam: } 80^{\circ} \mathrm{C} \text { for } 0 \mathrm{~min} \\
\text { then } 7{ }^{\circ} \mathrm{C} / \mathrm{min} \text { to } 280^{\circ} \mathrm{C} \text { for } 1 \mathrm{~min}\end{array}$ & Source type: $\mathrm{EI}$ \\
\hline Carrier gas: He, debit $1 \mathrm{ml} / \mathrm{min}$ & Electron energy: $70 \mathrm{eV} ;$ \\
\hline Injector temperature: $250^{\circ} \mathrm{C}$ & $\begin{array}{c}\text { Source temperature: } 230^{\circ} \mathrm{C} ; \\
\text { Temperature Aux } 2: 280^{\circ} \mathrm{C}\end{array}$ \\
\hline
\end{tabular}

Table 1

THE PARAMETERS FOR GS/MS ANALYSIS

Table 2

CHARACTERISTICS OF SRGO AND CO

\begin{tabular}{|c|c|c|c|c|c|c|c|}
\hline Characteristics & $\begin{array}{c}\text { Density } \\
\text { at } \mathbf{2 0} \mathbf{0}^{\circ} \mathbf{C} \\
\left(\mathbf{g} / \mathbf{c m}^{\mathbf{3}}\right.\end{array}$ & $\begin{array}{c}\text { Sulfur } \\
(\mathbf{p p m})\end{array}$ & $\begin{array}{c}\text { Viscosity at } \\
\mathbf{4} \mathbf{0}^{\circ} \mathrm{C} \\
\left(\mathbf{m m}^{2} / \mathbf{s}\right)\end{array}$ & $\begin{array}{c}\text { Freze } \\
\text { Point } \\
\left({ }^{\circ} \mathrm{C}\right)\end{array}$ & $\begin{array}{c}\text { Flash } \\
\text { point } \\
\left({ }^{\circ} \mathrm{C}\right)\end{array}$ & $\begin{array}{c}\text { Unsaturated } \\
\text { fatty acids } \\
(\%)\end{array}$ & $\begin{array}{c}\text { Saturated } \\
\text { fatty acids } \\
(\%)\end{array}$ \\
\hline SRGO & 0.8464 & 2316 & 4.2 & -16 & 58 & - & - \\
\hline CO & 0.9190 & - & 32.214 & -9 & 150 & 90.62 & 9.38 \\
\hline
\end{tabular}

Table 3

TBP DISTILLATION CURVE OF SRGO

\begin{tabular}{|c|c|c|c|c|c|c|c|c|c|c|c|}
\hline \% Vaporized & $\mathrm{t}_{\mathrm{i}}$ & 10 & 20 & 30 & 40 & 50 & 60 & 70 & 80 & 90 & 99 \\
\hline Temperature, ${ }^{\circ} \mathrm{C}$ & 186 & 235 & 250 & 268 & 285 & 296 & 302 & 315 & 320 & 332 & 345 \\
\hline
\end{tabular}

Table 4

THE CHEMICAL COMPOSITION OF CO

\begin{tabular}{|c|c|}
\hline Acid name & (\%) \\
\hline Myristic aid & 0.10 \\
\hline Palmitic acid & 6.51 \\
\hline Palmitoleic acid & 0.18 \\
\hline Stearic acid & 2.15 \\
\hline Oleic acid & 16.27 \\
\hline Linoleic acid & 20.99 \\
\hline Lonjugated Linolenic acid & 35.58 \\
\hline Linolenic acid (Omeg 3) & 11.59 \\
\hline Erucic acid & 1.60 \\
\hline Arachidonic acid & 1.11 \\
\hline Docasadieonic acid & 2.24 \\
\hline Other fatty acids & 0.61 \\
\hline
\end{tabular}

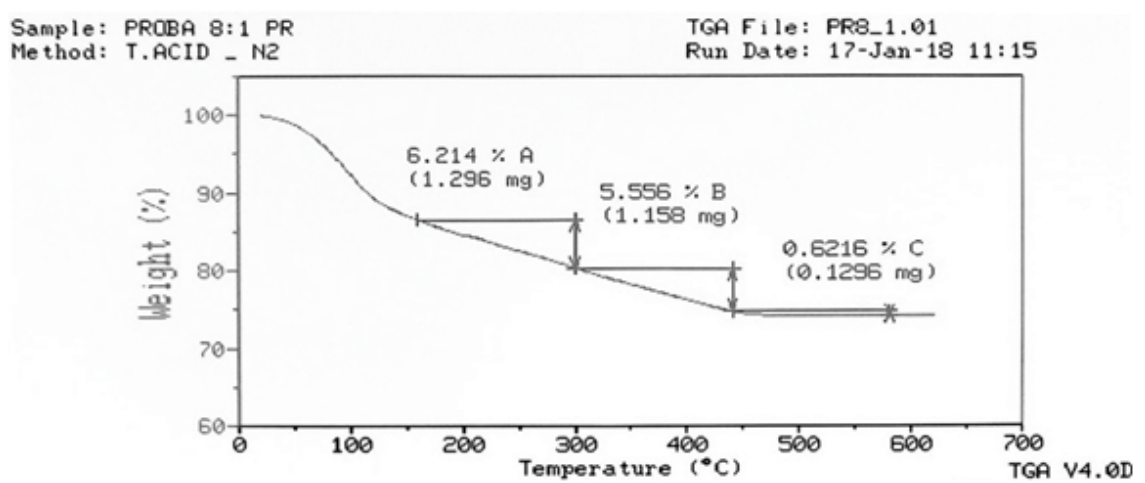

Fig. 2. Diethylamine desorption curve 
Table 5

ACIDIC STRENGHT AND ACIDITY DISTRIBUTION OF CATALYST

\begin{tabular}{|c|c|c|}
\hline \multirow{2}{*}{ Acidic centers } & Acidic strenght & $\begin{array}{c}\text { Distribution } \\
\text { of acidity }\end{array}$ \\
\cline { 2 - 3 } & Miliequivalent/g catalyst & $\%$ \\
\hline Weak & 0.850 & 50.14 \\
\hline Mediun & 0.760 & 44.83 \\
\hline Strong & 0.085 & 5.03 \\
\hline Total & 1.695 & 100.00 \\
\hline
\end{tabular}

The catalysts were activated by sulfurization, with dimethyl-disulphide (DMDS) solubilized in SRGO, to 4\%wt concentration, in the presence of hydrogen at a flow rate of $15 \mathrm{l} / \mathrm{h}, 280^{\circ} \mathrm{C}$ and 15 bar. Activation is completed after the $\mathrm{H}_{2} \mathrm{~S}$ formation in the reaction gases is revealed at the appearance of the yellow colour of cadmium acetate $5 \%$ aqueous solution, used as indicator.

By hydroconversion of only the $\mathrm{CO}$, it is obtained mostly n-paraffinic hydrocarbons with 17 and 18 carbons which are the result of the hydrocracking reactions of triglycerides followed by reactions of hydrodeoxygenation, hydrodecarbonylation, hydrodecarboxylation of the fatty acids according to the reaction from figure 3.

Following the hydrocracking reactions, it is obtained in small quantities hydrocarbons with $10-16$ carbons in the molecule. The chemical composition of the hydrotreated product is presented in table 6 ( LHSV $=1 h^{-1}$, pressure $=50$ bar) and chromatograms from figure 4 and 5 .
Table 6

THE CHEMICAL COMPOSITION OF THE PRODUCT FROM THE HYDROTREATING OF CAMELINA OIL

\begin{tabular}{|c|c|c|c|}
\hline \multirow{2}{*}{ Peak } & \multirow{2}{*}{ Components } & $\mathbf{3 5 0} \mathbf{}^{\circ} \mathbf{C}$ & $\mathbf{3 8 0}{ }^{\circ} \mathbf{C}$ \\
\cline { 3 - 4 } & & $\mathbf{\%} \mathbf{~ w t}$ & $\mathbf{\%} \mathbf{~ w t}$ \\
\hline 1 & Heptane & 0.64 & 0.73 \\
\hline 2 & Octane & 0.83 & 1.02 \\
\hline 3 & Nonane & 0.72 & 0.95 \\
\hline 4 & Decane & 0.66 & 1.11 \\
\hline 5 & Undecane & 0.86 & 1.29 \\
\hline 6 & Dodecane & 0.75 & 1.14 \\
\hline 7 & Tridecane & 0.67 & 1.09 \\
\hline 8 & Tetradecane & 0.53 & 1.03 \\
\hline 9 & Pentadecane & 3.69 & 4.15 \\
\hline 10 & Hexadecane & 6.05 & 7.04 \\
\hline 11 & Heptadecane & 27.4 & 26.6 \\
\hline 12 & Octadecane & 42.77 & 39.4 \\
\hline 13 & Nonadecane & 5.97 & 5.91 \\
\hline 14 & Eicosane & 8.56 & 8.54 \\
\hline & TOTAL & 100 & 100 \\
\hline
\end{tabular}

The paraffinic hydrocarbons with more than 17 carbons that have a boiling point greater than $300^{\circ} \mathrm{C}$, are distributed into the diesel fraction while the hydrocarbons with 10 to 16 carbons are distributed into the jet fraction. Analyzing the data from table 6 in correlation with the boiling points of the resulting hydrocarbons, we can conclude that we

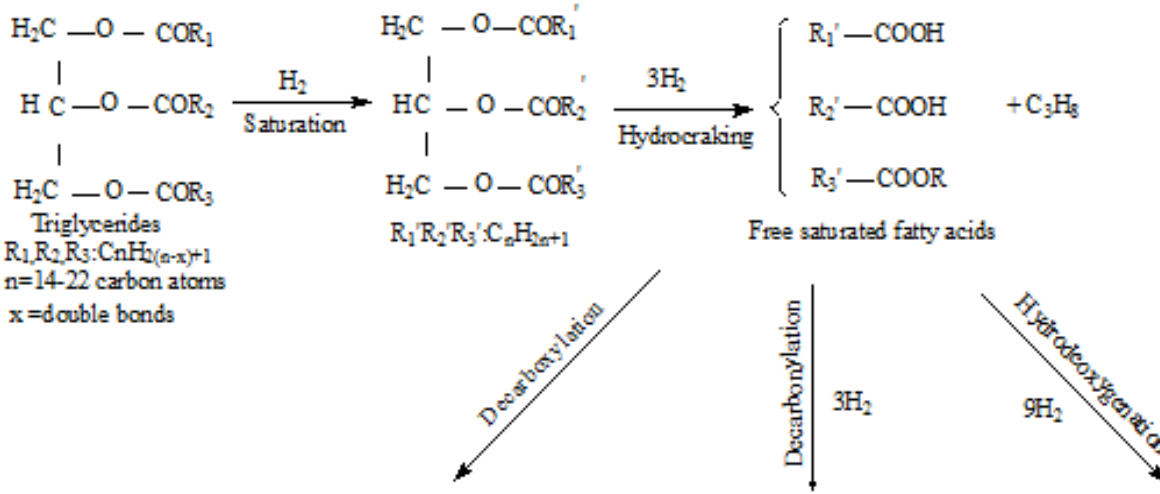

Fig. 3. Hydroconversion of triglygerides content in Camelina Oil

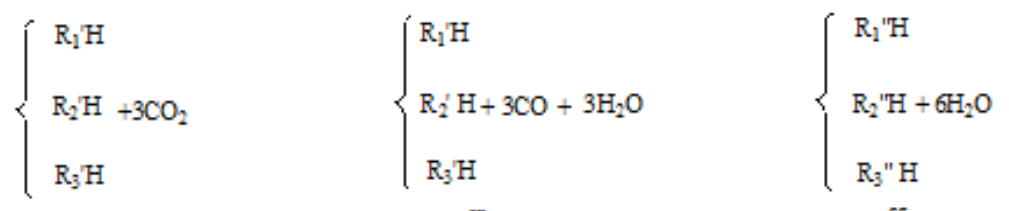

n paraffins nparaffins n paraffins

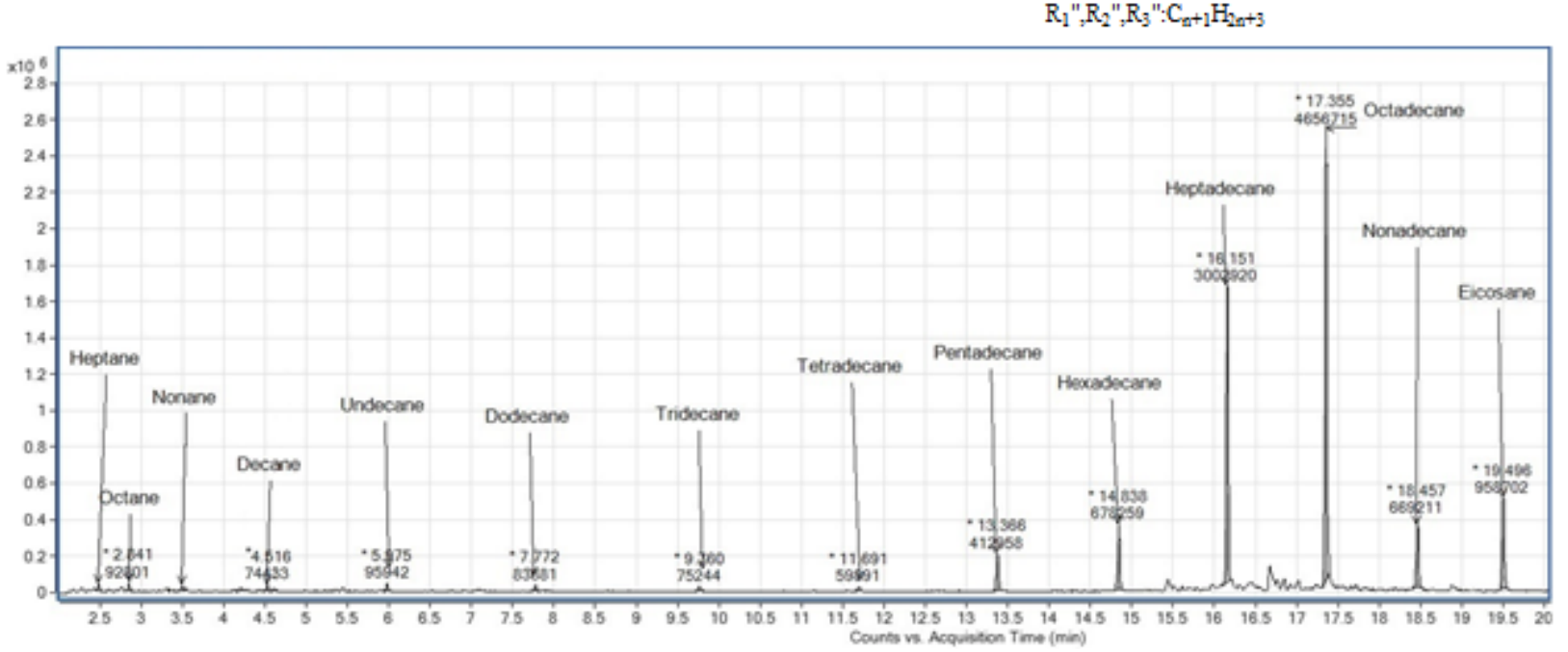

Fig.4. Chemical composition of the product resulted by hydrotreating the $\mathrm{CO}$ at $350^{\circ} \mathrm{C}$ 


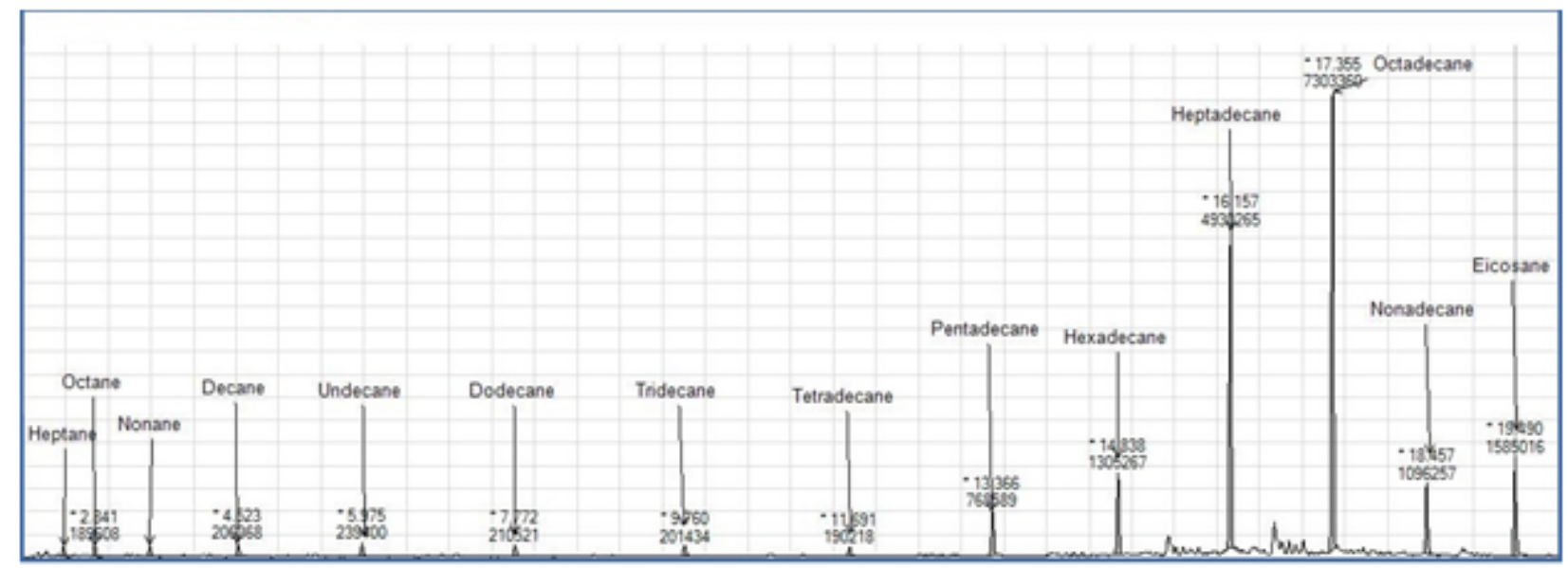

Fig.5. Chemical composition of the chemical product resulted by hydrotreating the $\mathrm{CO}$ at $380^{\circ} \mathrm{C}$

obtain mostly a diesel fraction and less jet fraction when hydrotreating the $\mathrm{CO}$ in the reaction conditions mentioned. Thereby, the hydrotreatment at $350^{\circ} \mathrm{C}$ results in $84.7 \%$ hydrocarbons with 17 to 20 atoms of carbon in the molecule that are distributed in the diesel fraction, while at $380^{\circ} \mathrm{C}$, we obtain $80.4 \%$. The fraction of heptadecane finds itself at the limit of fraction separation, the heptadecane having a boiling point of $302^{\circ} \mathrm{C}$, which could be included in the jet fraction and increasing the yield of this product with $27.4 \%$ if the hydtrotreatment is done at 350 and $26.6 \%$ if the hydrotreatment is done at $380^{\circ} \mathrm{C}$.

The increase of hydrotreating temperature has as effect the increase in yield of light fractions due to the intensification of the hydrocracking reactions. Also, another solution for increasing the yield in jet fuel would be the usage of more acidic catalysts, specific to hydrocracking, which would intensify the cracking reactions on one side and the isomerization on the other side so that there will be formed hydrocarbons with shorter carbon chains but with a branched structure and with boiling temperature specific to the distillation limits of the jet fuel fraction.

The yields of the products have been determined from mass balance for each experiment, knowing each quantity of feedstock and measuring through weighting the fractions of distilled from the hydrotreated liquid product after being dehydrated on $\mathrm{CaCl}_{\text {}}$. The difference between the quantity of feedstock and the dry hydrotreated liquid product, namely losses is made up out of gases, water and coke deposits on the catalyst.

The yields in products obtained at the hydroconversion of CO, SRGO and mixtures of CO/SRGO atdifferent reaction conditions are presented in in figure 6 to 9 .

The data obtained shows the higher yields in diesel and smaller yields in jetfuel, obtained from CO hydroconversion regardless of the reaction conditions, justified by the formation of hydrocarbons with 17-20 carbons in the molecule.

In the case of the hydroconversion of the SRGO, we obtained the highest yields of jet fuel due to the advantageous distribution of components having 10-16 carbons in the molecule in the SRGO which is clearly deducted from the TBP distillation curve (table 2) which shows that around $50 \%$ of the diesel is formed from components with boiling points within the jet fuel limits. Following the hydrotreating reactions, most of these components keep the same number of carbons or more, they hydrocracked and form lighter components.

At the same temperature and LHSV, the increase of the CO content in SRGO-CO mixture has as effect a drop in yield in jet fuel because as we showed above, through hydroconversion of the $\mathrm{CO}$ we obtain more diesel and less jet fuel. The increase in temperature for the hydroconversion, at the same CO content and same LHSV, leads to an increase of yield in jet due to the intensification of hydrocracking reactions which generate lighter components (figures 6-9).

The increase in LHSV while keeping the same CO/SRGO ratio and the reaction temperature, determines a drop in yield in jet fuel (figures 6-9) because of the shortening of the reaction time which would lead to a decrease of the conversion in hydrocracking reactions.

Following the hydroconversion reactions of $\mathrm{CO}, \mathrm{SRGO}$ and mixtures of CO/SRGO, we obtained small yields of

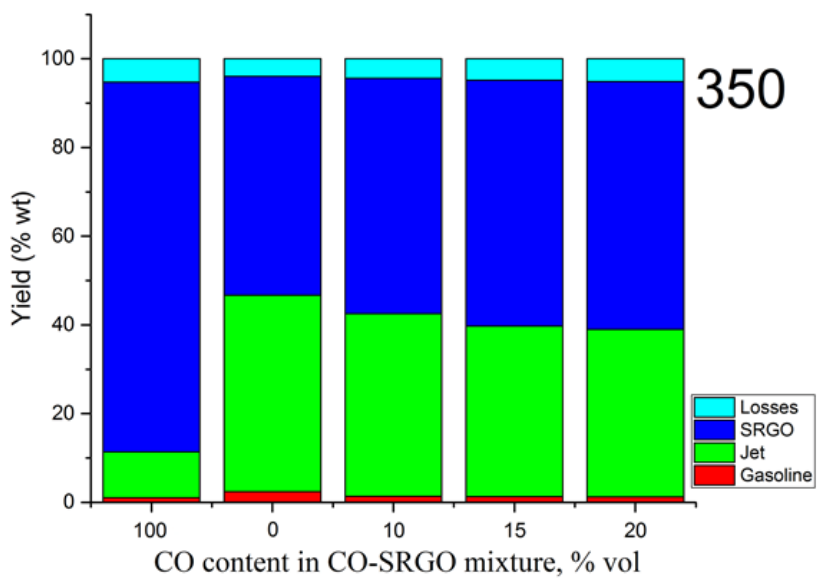

Fig.6. The influence of the $\mathrm{CO}$ content on the yields obtained at the hydroconversion of CO, SRGO and mixtures of CO-SRGO (temperature $350^{\circ} \mathrm{C}$, LHSV $=1 \mathrm{~h}^{-1}$, pressure $=50 \mathrm{bar}$ )

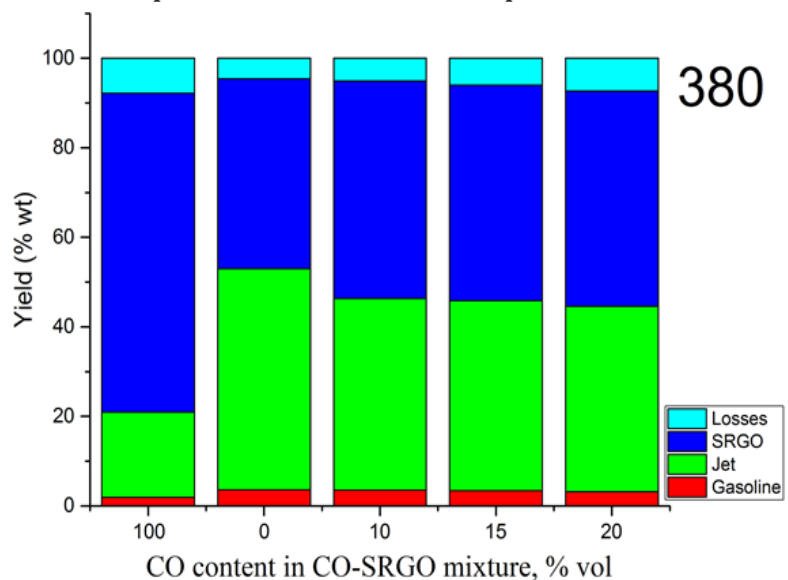

Fig.7. The influence of the CO content on the yields obtained at the hydroconversion of CO, SRGO and mixtures of CO-SRGO (temperature $380^{\circ} \mathrm{C}, \mathrm{LHSV}=1 \mathrm{~h}^{-1}$, pressure $=50$ bar) 


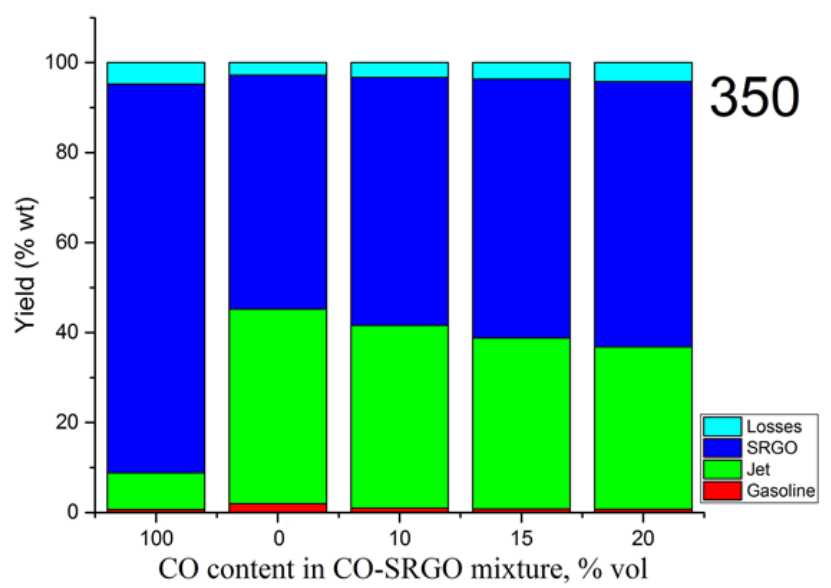

Fig.8. The influence of the $\mathrm{CO}$ content on the yields obtained at the hydroconversion of $\mathrm{CO}, \mathrm{SRGO}$ and mixtures of CO-SRGO (temperature $350^{\circ} \mathrm{C}$, LHSV $=1.5 \mathrm{~h}^{-1}$, pressure $=50 \mathrm{bar}$ )

light products (gasoline) with a final boiling point of $180^{\circ} \mathrm{C}$ but also gases, water and small quantities of coke that were deposited on the catalyst and are associated with losses. The presence of 7-9 carbons components has been highlighted by the GC-MS analysis of the reaction products obtained at the hydroconversion of the $\mathrm{CO}$. The light components (gasoline) are obtained through hydrocracking reactions from both the $\mathrm{CO}$ and SRGO. An increase in the $\mathrm{CO}$ content determines a small drop in the yield of gasoline. With the increase in temperature and decrease in LHSV at the same CO content, the yield in gasoline is increasing due to more intensified hydrocracking reactions. During the hydroconversion of the CO, gases are formed, especially propane and water which are the results of the hydrocracking, hydrodeoxygenation, hydrodecarnonylation, of triglyceride (figure 3). Small quantities of gases and coke are formed through hydrocracking reactions of the SRGO. The losses presented in figures 6-9 shows that the yields in gases and water are increasing with the content of $\mathrm{CO}$, with the temperature of reaction and decrease in LHSV. These growths are justified through the formation of propane and of water associated exclusively with hydroconversion of the triglycerides from the vegetable oil and with the intensification of the hydrocracking reactions, the increase of temperature and the decrease of LHSV. For the biojet obtained through hydrotreatment of CO-SRGO mixtures, the main physicochemical characteristics have been determined following the ASTM D1655 standard. The data is presented in figures 9 to 15.

The density of biojet obtained through hydrotreament of $\mathrm{CO}$ and SRGO has valuels between 0.8086 and $0.8168 \mathrm{~g} /$ $\mathrm{cm}^{3}$ and it falls in the limits of the ASTM D1655 standard for J et A1 fuel (density between $0.775-0.840 \mathrm{~g} / \mathrm{cm}^{3}$ ). Following the hydrotreating, the density drops significantly when compared with the density of the CO $\left(0.9190 \mathrm{~g} / \mathrm{cm}^{3}\right)$ and density of SRGO $\left(0.8464 \mathrm{~g} / \mathrm{cm}^{3}\right)$ due to the hydrocracking, hydrotreating and hydrodeoxygenation reactions of triglycerides from the $\mathrm{CO}$ thorough which the oxygen groups are eliminated and partially the paraffinic molecules with 17-20 atoms of carbon resulted from hydrotreating are broken down.

As well, the hydrocracking reactions determine a drop in density due to aromatic hydrocarbons being saturated and forming hydrocarbons with a smaller molecular mass comparatively with the components found in the SRGO. At the same CO content and LHSV, the increase in temperature determines a drop in density (figures10, 11) due to the deoxygenation reactions, hydrocracking and the

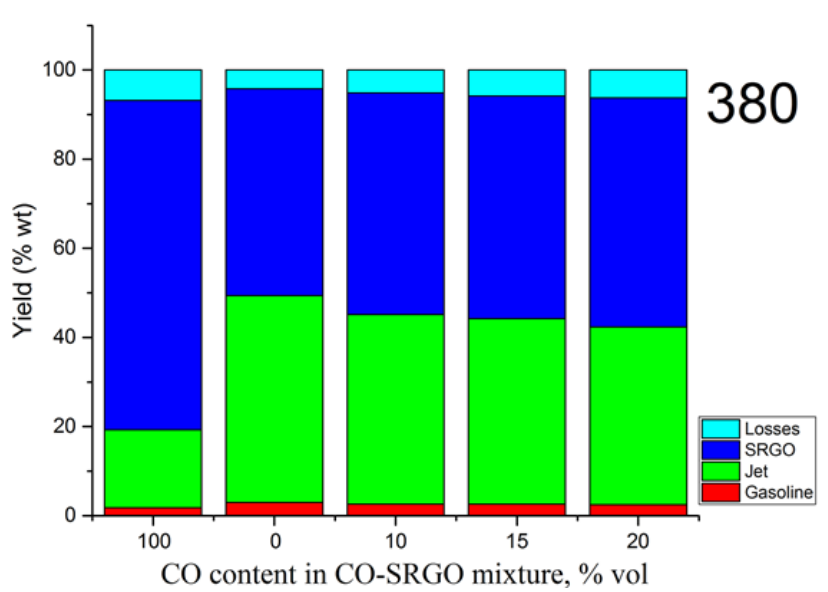

Fig. 9. The influence of the $\mathrm{CO}$ content on the yields obtained at the hydroconversion of CO, SRGO and mixtures of CO/SRGO

(temperature $380^{\circ} \mathrm{C}, \mathrm{LHSV}=1.5 \mathrm{~h}^{-1}$, pressure $=50 \mathrm{bar}$ )

saturation of aromatics in the diesel fraction. The density of the jet fuel obtained from hydroconversion of CO-SRGO mixture is slightly increasing with the content of $\mathrm{CO}$ (figures 10,11 ) due to the formation of paraffinic hydrocarbons with 18-20 carbons in the molecule, with a higher density, thro' inh hyidratrantina tha unantahlon nil

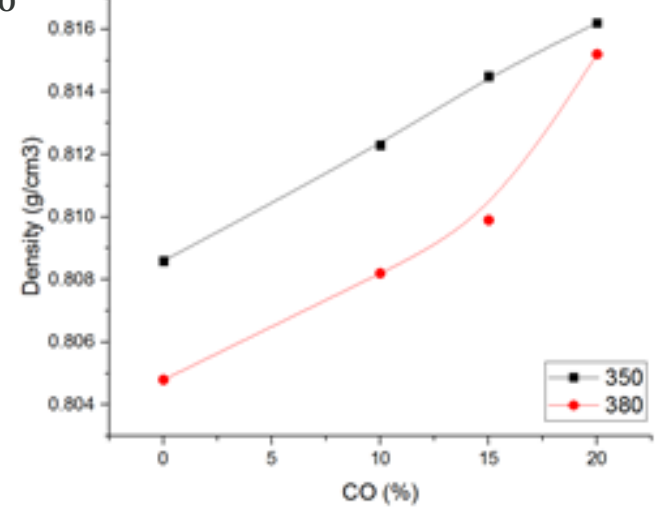

Fig.10. Density for jet fuel at $350^{\circ} \mathrm{C}$ and $380^{\circ} \mathrm{C}, \mathrm{LHSV}=1 \mathrm{~h}^{-1}$

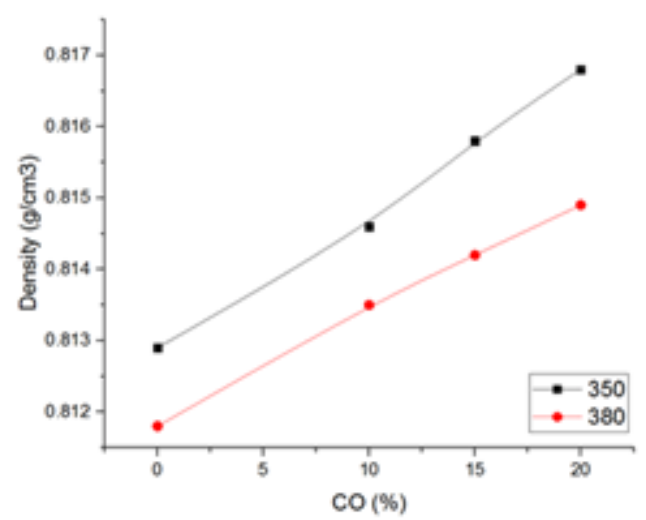

Fig.11. Density for jet fuel at $350^{\circ} \mathrm{C}$ and $380^{\circ} \mathrm{C}$, LHSV $=1.5 \mathrm{~h}^{-1}$

At the same temperature and $\mathrm{CO}$ content, the increase in LHSV (figures 10,11) determines a slight increase in density due to the diminution of the hydrocracking and hydrodeoxygenation reactions caused by the decrease of reaction time.

The freezing points for the biojet results from the hydrotreating the CO-SRGO mixtures are between -12 and $-20^{\circ} \mathrm{C}$, indifferent to the hydrotreating conditions (table 8,9). These temperatures are higher than the freezing temperature of imposed by the ASTM D1655 standard $\left(-47^{\circ} \mathrm{C}\right)$ and are justified due to the high content of $n-$ paraffins resulted from the hydrogenation of triglycerides from the $\mathrm{CO}$. Because of this, the freezing temperature of the biojet are increasing with the increase of the content 


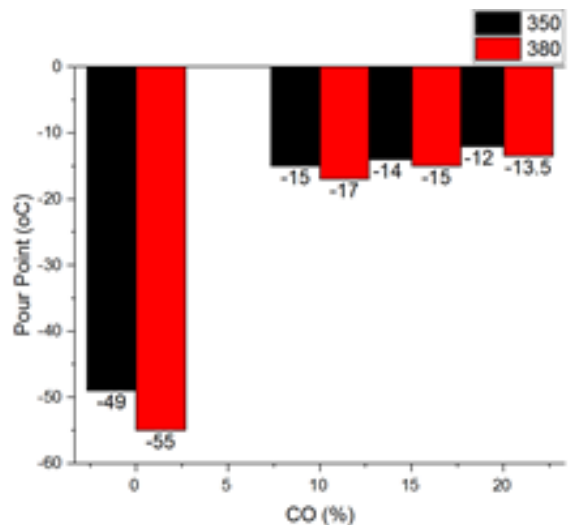

Fig. 12. Freeze point for jet fuel at $350^{\circ} \mathrm{C}$ and $380^{\circ} \mathrm{C}, \mathrm{LHSV}=1 \mathrm{~h}^{-1}$

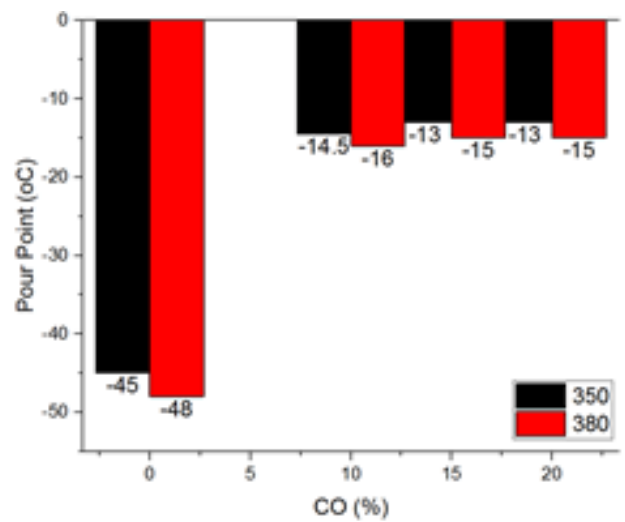

Fig. 13. Freeze point for jet fuel at $350^{\circ} \mathrm{C}$ and $380^{\circ} \mathrm{C}, \mathrm{LHSV}=1.5 \mathrm{~h}^{-1}$

of $\mathrm{CO}$ added into the mixture at a constant LHSV (table 8 and 9). From the increase of reaction temperature, due to intensification of secondary reactions of hydrocracking and hydroisomerisation, isoparaffins are formed that determine a slight decrease in the freezing temperature (figures 12,13).

At the same CO content and the same reaction temperature, the increase in LHSV does not improve the freezing temperature (figures 12,13 ) because it diminishing the conversion of hydrocracking reactions due to the decrease of reaction time.

In the case of the hydroconversion of only the SRGO, it is observed that the jet obtained meets the ASTM D1655 requirements, with flowing temperatures ranging between -52 to $-58^{\circ} \mathrm{C}$. The low freezing temperature are explained by the favorable chemical composition of the hydrotreated product, mostly made out of naphthenes resulted from the saturation of aromatics and from isoparaffins with 10-18 atoms of carbon that resulted from hydrocracking.

Through the hydroconversion, the sulfur content decrease significantly in comparison with the SRGO, from $2316 \mathrm{ppm}$ to a range between 15-48 ppm, falling into the limit of a maximum of $30 \mathrm{ppm}$ imposed by the ASTM 1655 standard with one exception, for the SRGO hydrotreatment at $350^{\circ} \mathrm{C}$ and LHSV of $\mathrm{h}^{-1}$, when the jet obtained has a sulfur content of $48 \mathrm{ppm}$. With the increase of the CO content, the sulfur content in the biojet resulted from the hydroconversion is decreasing because of the CO's lack of sulfur. The increase of temperature at the same LHSV determines a drop in sulfur content due to the intensification of the hydrogenolysis reactions of the sulfur components from the gas oil (figures 14,15). The increase of LHSV from $1 \mathrm{~h}^{-1}$ la $1.5 \mathrm{~h}^{-1}$ determines an increase of sulfur content in the biojet due to a decrease of the conversion in the hydrogenolysis reactions of the sulfur components from the gas oil due to the decrease in reaction time (figures $14,15)$.

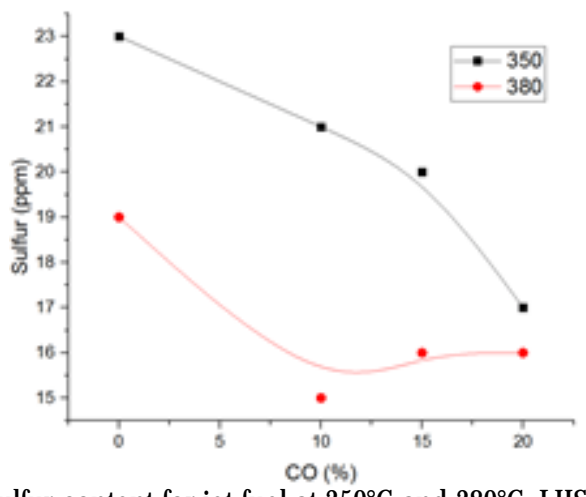

Fig. 14. Sulfur content for jet fuel at $350^{\circ} \mathrm{C}$ and $380^{\circ} \mathrm{C}$, LHSV $=1 \mathrm{~h}^{-1}$

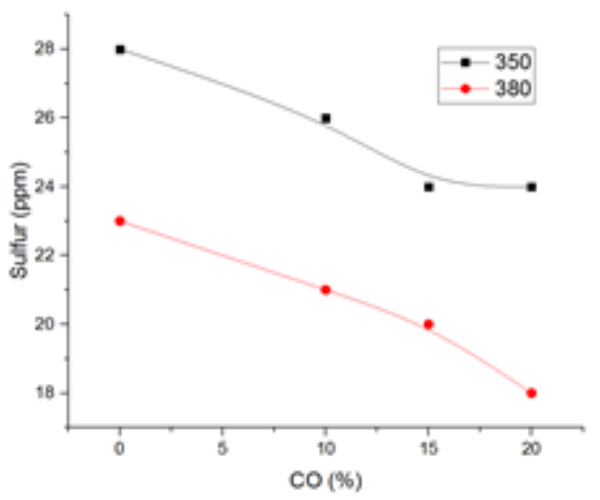

Fig. 15. Sulfur content for jet fuel at $350^{\circ} \mathrm{C}$ and $380^{\circ} \mathrm{C}, \mathrm{LHSV}=1.5 \mathrm{~h}^{-1}$

\section{Conclusions}

In the current research study, a mixture of $\mathrm{CO}$ and SRGO is proposed for hydroconversion on a NiMo/Al $\mathrm{O}_{3}$ catalyst, a 50 bar pressure and a temperature of $350^{\circ} \mathrm{C}, 380^{\circ} \mathrm{C}$ with a LHSV of 1 and $1.5 \mathrm{~h}^{-1}$, as an alternative for obtaining a biojetfuel.

Following the hydrogenation, decarbonylation, deoxygenation and hydrocracking of triglycerides from the vegetable oil, we observe a transformation in mostly linear paraffins $\mathrm{C}_{10}-\mathrm{C}_{20}$ The hetero compounds and heavier hydrocarbons from the SRGO are eliminated and respectively partial transformed in paraffins and alkyl naphtenes with a lower number of atoms of carbon through the hydrocracking and saturation reactions.

The results of the experimental study highlight the following:

- Hydroconversion of $\mathrm{CO}$ and straight run gas oil mixtures is a technologically accessible and a cost-effective process for the production of jet biofuels;

- Hydrogenation of esters and fatty acids from vegetable oil generates predominantly paraffinic hydrocarbon mixtures with 10-20 carbons in the molecules which improve the yields and the properties of jet fuel;

- Due to the high content in linear paraffinic hydrocarbons, the freezing point is inadequate in relation to the standard temperature.

\section{References}

1. RODRIGUE, J.-P., COMTOIS, C., SLACK, B., The Geography of Transport Systems, Third Edition, 2013, p. 263

2. Outlook for Energy, A View to 2040, ExxonMobil, 2018, p. 10

3. CHIARAMONTI, D., PRUSSI, M., BUFFI, M., TACONI, D., Applied Energy, 136, 2014, p.767

4. ICAO, International Civil Aviation Day Statement, 7 December 2018, Montreal, Canada, https://www.icao.int/Newsroom/Pages/InternationalCivil-Aviation-Day-Statement.aspx

5.*** International Civil Aviation Organization, Safety Report, 2018, p. 5 
6. ***European Commission, Annual Analyses of the EU Air Transport Market 2016, Final Report, March 2017, p. 9

7. ***International Air Transport Association, Industry Statistics - Fact Sheet, December 2018

8. ***International Air Transport Association, Climate Change \& CORSIA - Fact Sheet, May 2018, p. 2

9. CHENG, F., BREWER, C.E., Renewable and Sustainable Energy Reviews, 72, 2017, p.637

10. GUTIERREZ, A., GOMEZ-CASTRO, I.F., LIRA-FLORES, A.J., HERNANDEZ, S., Renewable and Sustainable Energy Reviews, 79, 2017, p.709

11. LIU, G., YAN, B., CHEN, G., Technical review on a jet fuel production, Renewable and Sustainable Energy Reviews, 2013, p. 60-61

12. WANG, W.-C., TAO, L., MARKHAM, J ., ZHANG, Y., TAN, E., BATAN, L., WARNER, E., BIDDY, M., Review of Biojet Conversion Technologies, National Renewable Energy Laboratory, 2016, p. 1-106

13. CORPORAN, E., EDWARDS, T., SHAFER, L., DEWITT, J., KLINGSHIRN, C., ZABARNICK, S., WEST, Z., STRIENBICH, R., GRAHAM, J., KLEIN, J., Chemical, Thermal Stability, Seal Swell and Emissions Studies of Alternative Jet Fuels, Energy and Fuels, 25, 2011, p. 1-31

14. CHUCK, C.J., Biofuels for Aviation, Elsevier, 2016 p. 39-392

15. EL TAKRITI, S., PAVLENKO, N., SEARLE, S., Mitigating International Aviation Emissions - Risks and Opportunities for Alternative J et Fuels, International Council on Clean Transportation, 2017, p. 3-36

16. WANG, C.W., TAO, L., Bio-jet fuel conversion technologies, Renewable and Sustainable Energy Reiews, 53, 2016, p.801

17. DOUKEH, R., BOMBOS, M., TRIFOI, A., PASARE, M., BANU, I., BOLOCAN, l., Dimethyldisulphide Hydrodesuphurization on $\mathrm{NiCoMo/}$ $\mathrm{Al}_{2} \mathrm{O}_{3}$ Catalyst, Rev. Chim. (Buchares), 68, 2017, p. 1496-1500

18. HULL, A., Production of J et Fuel from Ethanol and its Perspectives, EU-India Conference on Adcanced Bio Fuels, Swedish BioFuels AB, March 2018, p. 1-12

19. JOHNSTON, G., Alcohol to Jet - Isobutanol, ICAO Seminar on Alternative Fuels 2017, International Civil Aviation Organization, 2017, p.1-13

20. HU, F., Y., LU, Y., Apliation of Fisher Tropsch syntesis in biomas to liquid conversion, Catalysts, 2, 2012, p.303

21. BOICHENKO, S., VOVK, O., IAKOVLIEVA, A., Overview of Innovative Technologies for Aviation Fuels Production, Chemistry \& Chemical Technology, Vol. 7, No. 3, 2012, p. 1-8
22. STAVROS, M., Process Design, Economic Evaluation and Life Cycle Assessment of J et Fuel Production from Sugar Cane Residue, Wiley, 2017, p. 1-9

23.*** Sustainable Aviation Fuels Guide, International Civil Aviation Organization, 2017, p. 36

24.*** Biofuels for Aviation - Technology Brief, International Renewable Energy Agency, 2017, p. 8-38

25. SANTOS, C.I., SILVA, C.C., MUSSATTO, S.I., OSSEWEIJ ER, P., VAN DER WIELEN, L., POSADA, J.A., Integrated 1st and 2nd Generation Sugarcane Bio-Refinery for Jet Fuel Production in Brazil: TechnoEconomic and Greenhouse Gas Emissions Assessment, Renewable Energy, December 2018, p. 733-747

26. VASQUEZ, C.M., SILVA, E.E., CASTILLO, F.E., Hydrotreatment of vegetable oils: A review of the technologies and its developments for jet biofuel production, Biomass and Bioenergy, 105, 2017, p.197 27. FISK, S.V., Growing Camelina and Safflower in the Pacific Northwest, American Society of Agronomy, May 2014, p.1 www.agronomy.org/ science-news/growing-camelina-and-safflower-pacific-northwest

28. SAYED, M.H.T., HODA, T., GANTI, S.M., A regional life cycle assessment and economic analysis of camelina biodiesel production in the Pacific Northwestern US, J ournal of Cleaner Production, 2018, p. 2389-2400

29. KROHN, B.J ., FRIPP, M., A Life Cycle Assessment of Biodiesel Derived from the Niche Filling Energy Crop Camelina in the USA, Applied Energy, 2012, p. 92-94

30. MOSER, R.B., Camelina oil as biofuel feedstok:Golden opportunity or false hope,: Lipid Technology, 22, 2010, p.270

31. RAICIU, A. D., POPESCU, M., IVOPOL, G., C., BORDEI, N., ALEXANDRU, G., et al., Therapeutic Applications of Vegetable Oils and GC-MS Evaluation of $\omega-3, \omega-6$ and $\omega-9$ Amounts in Six Oleaginous Plants, Rev. Chim. (Bucharest), 67, 2016, p. 2449-2453

32. AVRAM, M., STROESCU, M., STOICA-GUZUN, A., FLOREA, O., Optimization of the Oil Extraction from Camelina (Camelina Sativa) Seeds Using Response Surface Methodology, Rev. Chim. (Bucharest), 66, 2015, p. 417-421

33. WORMSLEV, E., PEDERSE, J.L., ERIJSEN, C., BUGGE, R., et.a., Sustainable J et Fuel for Aviation - Nordic Perspectives on the use of Advanced Sustainable Jet Fuel for Aviation, Nordic Energy Research, 2016, p. 1-374

Manuscript received: 28.11 .2018 